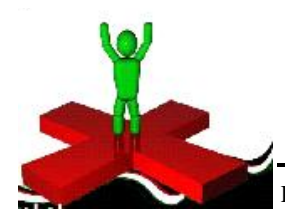

International Journal of Medical Sciences

DOI : 10.15740/HAS/IJMS/7.1and2/51-54 Volume 7|Issue 1\&2 |October, 2014|51-54

e ISSN-0976-7932 | Visit us - www.researchjournal.co.in

RESEARCH PAPER

\title{
Academic stress experienced by the undergraduate students and its influencing factors
}

\author{
VISHALA PATNAM AND JAYA BANGALE
}

See end of the paper for authors' affiliation

Correspondence to :

JAYA BANGALE

Department of Human

Developments and Family

Studies, College of Home

Science, Marathwada Krishi

Vidyapeeth, PRABHANI

(M.S.) INDIA

Email: bangalejaya @ gmail.

$\underline{\text { com }}$
ABSTRACT : A sample of 200 undergraduate students in the age range of 18-23 yrs of five colleges of Parbhani town of Marathwada region, Maharashtra State were studied. The data pertaining to the study were collected by personally interviewing the sample students based on open ended interview schedule and by administering on them the Battery of Academic Stress Scale (BASS) and Socio-Economic Status Scale. Irrespective of gender, 90 per cent of the students rated to have high level of academic stress followed by average level of it. Socio-economic status of both the male and female students and inter-personal relations maintained by female students with peers, teachers and neighbors were found to have significant negative correlation with their academic stress. Types of family of the male students and the parenting practices adopted for the students also recorded to have significant negative correlation with their academic stress. Academic frustration was significantly higher in male students as compared to their female counterparts. Therefore, it becomes the prime responsibility of the parents, teachers and institutional authorities to come up with the appropriate strategic action to reduce stress of the students and also enable them to manage academic stress at ease without affecting their development and mental health.

How to cite this paper : Bangale, Jaya and Patnam, Vishala (2014). Academic stress experienced by the undergraduate students and its influencing factors. Internat. J. Med. Sci., 7(1\&2) : 51-54.

\section{KEY WORDS :}

Academic stress,

Components of stress 